\title{
The Reproductive Performance of Ongole Grade Cows at Smallholder Farmer with Different Housing Systems
}

\author{
Bryan Wisnu Prabowo ${ }^{1}$, Endang Baliarti ${ }^{2, *}$, Sigit Bintara ${ }^{3}$, Hamdani Maulana ${ }^{2}$, Bayu \\ Andri Atmoko ${ }^{2}$ \\ ${ }^{1}$ Graduate Student of Faculty of Animal Science, Universitas Gadjah Mada, Fauna 03, Bulaksumur, Yogyakarta, \\ Indonesia (55821). \\ ${ }^{2}$ Department of Animal Production, Faculty of Animal Science, Universitas Gadjah Mada, Fauna 03, Bulaksumur, \\ Yogyakarta, Indonesia (55821) \\ ${ }^{3}$ Department of Animal Breeding and Reproduction, Faculty of Animal Science, Universitas Gadjah Mada, Fauna 03, \\ Bulaksumur, Yogyakarta, Indonesia (55821). \\ *Corresponding author. Email: bali_arti@ugm.ac.id
}

\begin{abstract}
Ongole grade (OG) cows are mostly kept at the smallholder farmer level, carried out traditionally - for instance, on the cow's housing system, using individual tie-stall (ITS), or communal tie-stall (CTS) system. The housing system can affect the reproductive performance of the cows. This study aims to determine the better type of housing to be applied at the smallholder farmer level based on reproductive performance. Forty-three OG cows were divided into the ITS ( $n=20$ cows) and CTS ( $n=23$ cows) systems. Post-partum estrus (PPE), post-partum mating (PPM), weaning age (WA), service per conception (S/C), calving interval (CI), and calf crop (CC) as reproductive performance indicator were collected through farmer recording, then were analyzed using the independent sample t-test. The results showed that the type of communal tie-stall was significantly better on S/C, WA, CI, and CC. In conclusion, using a communal tie-stall housing system was better for OG cow's reproductive performance.
\end{abstract}

Keywords: Reproductive Performance, Ongole Grade Cattle, Housing System, Smallholder Farmer

\section{INTRODUCTION}

The average meat consumption in Indonesia is 2.72 $\mathrm{kg} / \mathrm{capita} / \mathrm{yr}$ and is projected to increase in the next few years along with the increase in population, income, and consumption of animal protein [1]-[3]. This condition requires an increase in livestock productivity to meet the needs of beef in the future. However, the majority of beef cattle breeding is at smallholder farmers. The majority of smallholder farmers are on the island of Java, with the breed of livestock is Ongole Grade (OG) cattle. Ongole Grade cattle have good adaptability to environmental and feed conditions in the territory of Indonesia [4]. Smallholder farmers mostly do maintenance of OG cattle with ownership of 1-5 heads [5]. The purpose of having cattle is as a saving or a side business so that farmers do not focus too much on raising cattle [6], [7]. Maintenance is carried out with traditional methods with different approaches. Generally, smallholder farmers get knowledge of cattle maintenance from their parents. Older farmers have more experience than younger farmers [8], [9], which makes cattle management from one farmer to another different. Differences in management by breeders affect the reproductive performance of cattle [8], [10].

Differences in cattle maintenance can be seen in feeding, caring, and housing. The type of housing used in smallholder farmers is usually a group or individual system, with the cattle being tied all the time. The housing with a group system will make it easier for farmers to observe their cattle. In addition, cattle also have access to interact with other cattle. This condition will affect the reproductive performance of the cattle. In addition, smallholder farmers generally do not raise bulls, 
whereas research [11] states that the presence of bulls can make cows express better sexual behavior, which certainly can improve the reproductive performance of cows. Reproductive performance can be seen from S/C, PPE, calving interval (CI), and calf crops [12], [13]. A good $\mathrm{CI}$ is around 12 months so that farmers can get a calf every year. However, this condition is still difficult to achieve with the traditional farming system. This research was conducted to determine the most appropriate type of housing at the farmer level to obtain better reproductive performance. Thus, it can be used to recommend a better housing system for smallholder farmers.

\section{MATERIAL AND METHODS}

This study used 43 OG cows that have calved at least once in a farmer group in Sleman Regency, Yogyakarta. Twenty OG cows were kept in individual tie-stall (ITS) or communal tie-stall (CTS) housing systems. Cows were mated using artificial insemination. The feed given to the cows was forage from the local area. Cows' productivity data was obtained from the recording results, including PPE, PPM, weaning age, S/C. The CI and calf crop (CC) were calculated using the formula:

Data on PPE, PPM, weaning age, S/C, CI, and CC were analyzed using the independent sample T-Test.

\section{RESULTS AND DISCUSSION}

The result of this research is described in Table 1.

Table 1. Ongole grade cow productivity

\begin{tabular}{|l|c|c|}
\hline \multirow{2}{*}{ Parameters } & \multicolumn{2}{c|}{ Housing } \\
\cline { 2 - 3 } $\begin{array}{l}\text { Weaning age } \\
\text { (month) }\end{array}$ & $7.10 \pm 1.80^{\mathrm{a}}$ & $4.43 \pm 0.99^{\mathrm{b}}$ \\
\hline PPE (month) ns & $4.15 \pm 1.50$ & $3.70 \pm 1.02$ \\
\hline PPM (month) ${ }^{\mathrm{ns}}$ & $5.10 \pm 1.45$ & $5.48 \pm 1.34$ \\
\hline S/C (times) & $4.95 \pm 4.66^{\mathrm{a}}$ & $1.74 \pm 0.96^{\mathrm{b}}$ \\
\hline Cl (month) & $17.02 \pm 3.16^{\mathrm{a}}$ & $15.45 \pm 1.60^{\mathrm{b}}$ \\
\hline CC (\%) & $72.37 \pm 10.96^{\mathrm{a}}$ & $78.52 \pm 8.72^{\mathrm{b}}$ \\
\hline
\end{tabular}

a,b Different superscripts denote significant differences between rows $(\mathrm{P}<0.05)$.

${ }^{\text {ns }}$ Non-significant

Ongole grade cows in ITS and CTS housing systems showed significant differences in weaning age $(\mathrm{P}<0.05)$. The preference of the farmers influences weaning age. In the ITS system, farmers give the calf a longer time with its mother because it is still suckling. Meanwhile, the cattle in CTS, the farmers weaned the calf after the calf had an excellent performance. In addition, farmers also have better communication between farmers to exchange ideas about the best cow productivity. The weaning age of calves in ITS is still higher than the study [4] in
Kebumen, with a weaning age of $5.96 \pm 2.90$ months. Faster weaning can increase the reproductive efficiency of the cows [14]

Weaning affects the longer ovulation time in the cows. Ovulation can occur 15-30 days after calving, but cows do not show estrus behavior [15]. In lactating cows, there is the production of the hormone prolactin, which affects the regulation of estrogen and progesterone to the hypothalamus. The estrogen plays a vital role in the estrus phase, with the appearance of visual signs of estrus [16]. The cows' PPE in the ITS and CTS system did not significantly differ $(\mathrm{P}>0.05)$. The study results [17] on OG cows showed no difference (3.45 months).

The results on cows' PPM between ITS and CTS system did not show significant differences. These results are longer than the results of the study [18], which is $4.33 \pm 0.38$ months. Differences in PPM can be affected by the ability of estrus detection and delay in mating because the calf is still suckling. Farmers in this research chose not to mate their cows after the first sign of estrus appeared but to mate in the subsequent estrus, making the PPM longer.

There is a significant difference in the number of S/C in the ITS and CTS system. Ongole grade cows in Pacitan have an average of S/C of $1.71 \pm 0.87$ times [19]. The S/C number in the CTS system ranged from 1 to 5 times, while the ITS system varied from 1 to 19 times. This condition is economically unfavorable for smallholder farmers, and the problematic cow should have been culled. However, farmers were happy with their cows and did not want to change them with other cows. Farmers use cow waste as fertilizer. It was speculated that the factors affecting the high S/C rate in the ITS system were the lack of communication between farmers, the cows experiencing silent heat, and the frequency of farmers to the farm. In the CTS system, farmers can observe each other cows and see cows in estrus. Farmers will notify cow owners when cattle are in estrus so that mating can be carried out on time and reduce the possibility of repeated mating. One of the factors that influence the high rate of repeated mating and S/C is the ability of farmers to detect estrus [11].

The calving interval for OG cows is 15.63 months [20]. The calving interval was affected by PPE, PPM, $\mathrm{S} / \mathrm{C}$, age at first mating, mating management [21][22]. This study showed that there were significant differences between the cows in the ITS and CTS system. Individual tie-stall housing systems have longer CI due to high S/C numbers. Longer calving intervals indicate lower reproductive efficiency [23].

The longer CI is the result of the high incidence of postpartum anestrus and high $\mathrm{S} / \mathrm{C}$ rate. Calving interval affects the reproductive performance of the cows in one year [24]. The CC in the CTS system was significantly 
higher than in the ITS system. The study results were still lower than the study [25] in OG cattle, $82.61 \%$.

\section{CONCLUSION}

In conclusion, the maintenance of $\mathrm{OG}$ cows in a communal tie-stall housing system is better than the individual tie-stall housing system. This result can be a recommendation for cattle breeding development at smallholder farmers.

\section{AUTHORS' CONTRIBUTIONS}

BWP was doing research in the field. EB prepared a research proposal, was responsible for laboratory tests and was involved in data analysis, results, and discussion. $\mathrm{SB}, \mathrm{HM}$, and BAA was involved in data analysis, results, and discussion.

\section{ACKNOWLEDGMENTS}

The author would like to thank the Universitas Gadjah Mada, who has supported this research financially through student Final Project Recognition 2021, and all respondents have given permission and provided research material.

\section{REFERENCES}

[1] A. Agus and T. S. M. Widi, Current situation and future prospects for beef cattle production in Indonesia - A review, Asian-Australasian Journal of Animal Sciences, vol. 31, no. 7, pp. 976-983, 2018,DOI: https://doi.org/10.5713/ajas.18.0233

[2] H. Koesmara et al., Income over feed cost of Aceh cattle fattened with forage and concentrate in different levels, IOP Conference Series: Earth and Environmental Science, vol. 387, no. 1, 2019,DOI: https://doi.org/10.1088/1755-1315/387/1/012101

[3] I. G. S. Budisatria, A. Ibrahim, H. Koesmara, E. Baliarti, T. S. M. Widi, and B. A. Atmoko, Income Analysis and Market Profile of Live Cattle and Meat Traders during Meugang Festivity and Normal Market Situation in North Aceh Regency, IOP Conference Series: Earth and Environmental Science, vol. 372, no. 1, 2019,DOI: https://doi.org/10.1088/1755-1315/372/1/012013

[4] N. Ngadiyono, P. Panjono, S. P. S. Budhi, and A. E. Susanti, Characteristics of Ongole Grade Cows in the Kebumen Regency, Central Java Province, International Seminar on Tropical Animal Production (ISTAP), vol. 0, no. 0, pp. 835-839, 2017, [Online]. Available: https://journal.ugm.ac.id/istapproceeding/article/vie w/30031
[5] Soeharsono, R. A. Saptati, and K. Diwyanto, Kinerja Reproduksi Sapi Potong Lokal dan Sapi Persilangan Hasil Inseminasi Buatan di Daerah Istimewa Yogyakarta (Reproductive Performances of Local and Crossbred Beef Cattle Resulting from Artificial Insemination in the Special Region of Yogyakarta), Seminar Nasional Tekhnologi Peternakan dan Veteriner, no. Ci, pp. 89-99, 2010.

[6] F. H. Elly, Pengembangan usaha ternak sapi rakyat melalui integrasi sapi-tanaman di Sulawesi Utara, Jurnal Pertanian dan Pengembangan Pertanian, vol. 27, no. 2, pp. 63-68, 2008

[7] A. Ibrahim, I. G. S. Budisatria, E. Baliarti, and T. S. M. Widi, The estimation of aceh cattle output in north aceh regency, in Simposium Nasional Penelitian dan Pengembangan Peternakan Tropik Tahun 2016 "Pengembangan Peternakan Berbasis Plasma Nutfah dan Kearifan Lokal Mendukung Agroekologi Berkelanjutan", 2016, pp. 222-233.

[8] I. G. S. Budisatria, E. Baliarti, T. S. M. Widi, A. Ibrahim, and B. A. Atmoko, Reproductive Management and Performances of Aceh Cows, Local Indonesian Cattle Kept by Farmers in A Traditional System, American-Eurasian Journal of Sustainable Agriculture, vol. 13, no. 3, pp. 21-31, 2019,DOI:

https://doi.org/10.22587/aejsa.2019.13.3.3

[9] A. Ibrahim, D. Setyo Wibowo, I. Gede Suparta Budisatria, R. Widayanti, and W. Tunas Artama, Relationship Between Sheep Farmer's Characteristics with the Animal and Environmental Health Management Practices in Batur Village, Banjarnegara, Indonesia, BIO Web of Conferences, vol. 33, p. 04010, 2021,DOI: https://doi.org/10.1051/bioconf/20213304010

[10] I. G. S. Budisatria, B. Guntoro, A. E. T. Sulfiar, A. Ibrahim, and B. A. Atmoko, Reproductive management and performances of Bali cow kept by smallholder farmers level with different production systems in South Konawe Regency, Indonesia, IOP Conference Series: Earth and Environmental Science, vol. 782, no. 2, p. 022079, 2021,DOI: https://doi.org/10.1088/1755-1315/782/2/022079

[11] E. Baliarti et al., Sexual behaviors of Ongole Crossbred bulls and cows with colony housing system, IOP Conference Series: Earth and Environmental Science, vol. 465, no. 1, p. 012045, 2020,DOI: https://doi.org/10.1088/1755$1315 / 465 / 1 / 012045$

[12] B. Atmoko, E. Baliarti, and N. A. Fitriyanto, IPTEK Bagi Masyarakat ( IbM ) Melalui Peningkatan Panen Pedet dan Produksi Kompos Berkualitas Pada 
Kelompok Ternak Sapi Potong induk yang kurang baik . Dilihat dari indikator angka rata-rata service per conception, Jurnal Pengabdian Kepada Masyarakat-Indonesian Journal of Community Engagement, vol. 5, no. 1, pp. 72-98, 2019,DOI: https://doi.org/http:..doi.org/10.22146/jpkm.33874

[13] I. G. S. Budisatria, E. Baliarti, T. S. M. Widi, and A. Ibrahim, Dynamics population of Aceh and non Aceh cattle in North Aceh Regency, in Simposium Penelitian dan Pengembangan Peternakan Tropik, 2016, pp. 236-243.

[14] R. P. Wettemann, C. A. Lents, N. H. Ciccioli, F. J. White, and I. Rubio, Nutritional- and sucklingmediated anovulation in beef cows1, Journal of Animal Science, vol. 81, no. 14_suppl_2, pp. E48E59, Feb. 2003,DOI: https://doi.org/10.2527/2003.8114_suppl_2E48x

[15] H. J. Bearden, J. W. Fuquay, and S. T. Willard, Applied Animal Reproduction, 6th editio. United States of America: Pearson Education, Inc., 2004.

[16] M. Ramli, T. N. Siregar, C. N. Thasmi, Dasrul, S. Wahyuni, and A. Sayuti, Relation between Estrous Intensity and Estradiol Concentration on Local Cattle during Insemination, Jurnal Medika Veterinaria, vol. 10, no. 1, pp. 27-30, 2016.

[17] E. Baliarti et al., Postpartum Oestrus Variation of Local Cows at a Village Breeding Centre in Yogyakarta, Indonesia, in Proceeding of the 1st International Conference on Tropical Agriculture, 2017, pp. 377-381.

[18] T. Riatnawati, Karakteristik dan kinerja induk sapi peranakan ongole dan sapi silangan simmental dengan peranakan ongole di Kecamatan Mlati, Kabupaten Sleman, Universitas Gadjah Mada, 2010.

[19] A. Rastosari, M. Herawati, and N. E. Wati, Reproduction Performance of Ongole Grade Cows and Its Crossbreds in Pacitan Regency, East Java Province, Indonesia, Journal of Physics: Conference Series, vol. 1155, no. 1, pp. 8-12, 2019,DOI: https://doi.org/10.1088/1742-6596/1155/1/012018

[20] T. S. M. Widi et al., Is cross-breeding of cattle beneficial for the environment? The case of mixed farming systems in Central Java, Indonesia, Animal Genetic Resources/Ressources génétiques animales/Recursos genéticos animales, vol. 57, no. October, pp. 1-13, 2015,DOI: https://doi.org/10.1017/s2078633615000259

[21] A. Budiawan, M. N. Ihsan, and S. Wahjuningsih, Relationship Between Body Condition Score With
Service Per, J. Ternak Tropika, vol. 16, no. 1, pp. 34-40, 2015.

[22] L. W. Fauziah, W. Busono, and G. Ciptadi, Performans reproduksi sapi peranakan ongole dan peranakan limousin pada paritas berbeda di Kecamatan Paciran Kabupaten Lamongan, J. Ternak Tropika, vol. 16, no. 2, pp. 49-54, 2015.

[23] F. F. Dirgahayu, M. Hartono, and P. E. Santosa, Conception Rate Pada Sapi Potong Di Kecamatan Jati Agung, Jurnal Ilmiah Peternakan Terpadu, vol. 3, no. 1, pp. 7-14, 2015, [Online]. Available: https://jurnal.fp.unila.ac.id/index.php/JIPT/article/v iewFile/673/615

[24] E. Baliarti, I. Gede Suparta Budisatria, Panjono, B. Andri Atmoko, and H. Maulana, Calf production of Bali cows in cattle-oil palm plantation integration system in Riau Province Indonesia, IOP Conference Series: Earth and Environmental Science, vol. 518, no. $1, \quad$ pp. $8-11, \quad 2020$,DOI: https://doi.org/10.1088/1755-1315/518/1/012015

[25] M. Muntaha, Panen pedet dari bangsa yang berbeda di tempat pembuangan akhir Piyungan Bantul Yogyakarta, Universitas Gadjah Mada, 2011. 